University for Business and Technology in Kosovo

UBT Knowledge Center

UBT International Conference

2017 UBT International Conference

Oct 27th, 3:00 PM - 4:30 PM

\title{
Project Management for Enterprise Architecture Evaluation
}

Malgorzata Pankowska

University of Economics in Katowice, Poland, pank@ue.katowice.pl

Follow this and additional works at: https://knowledgecenter.ubt-uni.net/conference

Part of the Business Commons

\section{Recommended Citation}

Pankowska, Malgorzata, "Project Management for Enterprise Architecture Evaluation" (2017). UBT International Conference. 235.

https://knowledgecenter.ubt-uni.net/conference/2017/all-events/235

This Event is brought to you for free and open access by the Publication and Journals at UBT Knowledge Center. It has been accepted for inclusion in UBT International Conference by an authorized administrator of UBT Knowledge Center. For more information, please contact knowledge.center@ubt-uni.net. 


\title{
Project Management for Enterprise Architecture Evaluation
}

\author{
Malgorzata Pankowska ${ }^{1}$ \\ ${ }^{1}$ University of Economics, Computer Science Department, 50, 1 Maja Street, \\ 40287 Katowice, Poland \\ malgorzata.pankowska@ue.katowice.pl
}

\begin{abstract}
The Enterprise Architecture (EA) describes overarching designs of individual physical and logical components, so that they assembly results in a complete and working product. The designs are developed within any projects. The designs concern computer systems and network implementation, software development and installation, data migration and business processes reengineering. The paper supports the thesis that EA is a complex of information communication technology (ICT) projects and as such should be evaluated by deployment of cost-benefit investment evaluation methods usually applied for project management. The main goal of the paper is to present opportunities of enterprise architecture evaluation by project evaluations. In the paper, different projects, i.e., multiproject, project portfolio, project programme, roll-out projects, large project, are discussed in the aspect of their value creation in the Enterprise Architecture development process.
\end{abstract}

Keywords: enterprise architecture, project management, architecture evaluation, project portfolio, project programme, multi-project.

\section{Introduction}

Generally, the enterprise architecture (EA) is the discipline of designing enterprises guided with principles, frameworks, methodologies, requirements, tools, reference models, and standards. The EA is responsible for designing structures, engineering processes, developing working force, exploiting technology and creating opportunities of learning.

For the purpose of this paper, the enterprise architecture realization model is a big project or a set of ICT applications in the enterprise to achieve strategic business goals. The enterprise architecture model is to explain why organizations do what they do and how they can be changed to achieve a certain demanded purpose. The complete picture of the enterprise architecture should include answers to the following questions: what will be done i.e., what products, services and experiences, who will do the work, how, when and where the work will be done, who will be offered the results, what legal regulations permit it to be done, what costs are necessary, why customers are expected to pay for what they receive, what technologies will be developed and applied. The EA realization model communicates a compelling vision of usage of ICT within a business organization and within its contracts with the business environment and ICT providers to coordinate organizational strengths with environmental opportunities, to guide and coordinate supporting activities, to generate more benefits than costs and to explore new opportunities, and to respond to new user requirements. A project-oriented approach emphasizes the comprehensive and cohesive specification of an enterprise projects in all their details, from a high level development. This approach focuses on essential project investments decisions, as well as on the 
core structures of projects. When taking this approach, EA developers typically produce models that describe all the projects' artefacts and their interrelations.

The paper consists of two main parts. The first part covers interpretation of EA in the context of its frameworks, and characterizes different approaches to EA evaluation developed by practitioners and academic environment. The second part includes considerations on EA evaluations as a complex of ICT projects.

\section{Enterprise Architecture Evaluation Characteristics}

ISO/IEC/IEEE 42010 standard architecture is the fundamental organization of a system embodied in its components, their relationships to each other and to the environment, as well as the principles guiding its design and evolution. The EA as a product serves to guide managers in designing business processes and system developers in building applications in a way that is in line with business objectives and policies [6]. The EA as a process is to translate business vision and strategy into effective ICT components. It should be noticed that enterprise models are applied as a computational representation of the structure, activities, processes, information, people, goals, and constraints of a business. The EA goals are to promote business-IT alignment, standardization, reusability of existing ICT assets and to share a common model for project management and software development across the organization.

The EA is to ensure a holistic view of the business processes, systems, information, and technology of the enterprise. The results of work of enterprise architect cover the derived IT strategies, a new and modified EA, the new and modified set of EA standards, and a roadmap describing the ICT projects for the implementation of the new architecture and achieving the target state, and a development plan [9].

The EA frameworks emphasize the modelling part of EA development and they do not considered any methods which strictly belong to economics [9]. The EA frameworks' developers separate EA evaluation from EA implementation. They perceive the necessity to ensure a coherence among different models, they analyse the convergence of proposed models, their scalability, openness, agility, sustainability and ability to ensure security. However, the real value in the enterprise architecture is revealed in the EA implementation. There are some important questions, which could be answered in the proposed paper. How evaluate the contribution of EA to the project? How estimate the value of the EA before starting of its implementation? For some enterprise architects the economic value problems are out of scope. They considered EA as never ending process, for which it is impossible to specify all detailed projects for a specified periods of time.

The EA project-oriented development should be placed in the context of Enterprise Architecture Lifecycle, which includes the following phases: Enterprise Strategy, Enterprise ICT strategy, Enterprise Architecture Process and Approach, Enterprise Architecture Models and Designs, ICT Projects for Designs Implementation, Projects' Evaluations, Maintaining the Enterprise Architecture. The first stage covers description of the value of an EA and the relationships of the EA to enterprise strategic vision and plans. Next, the business strategies are translated into ICT strategy, and EA goals, objectives and strategies. For the third stage, the enterprise employees commitment is necessary for the development, implementation and maintaining the EA. The basic stage in the EA lifecycle includes modelling and designing the business processes, data, software applications and hardware configurations. That activities are divided into ICT projects. For each domain, i.e., business processes, data models, applications development, security systems, and computer networks and hardware configuration and implementation, the separate projects are developed. The projects are mutually interdependent. They are realized simultaneously or one after another. The project portfolio is developed according to the EA models. 


\section{Enterprise Architecture Evaluation Characteristics}

Evaluating refers to systematic activities undertaken to describe and visualize particular phenomena in a structured and formal way. The enterprise architecture evaluation is to describe enterprise objectives, activities, information resources, processes, actors, products, requirements and the relationships between these entities.

The Business - Information Technology Alignment (BITA) models applied for EA evaluation should cover at least two aspects: strategic fit and functional integration. According to Van Grembergen, the strategic fit should recognize that the ICT strategy should be articulated in terms of an external domain - how the firm is positioned in the IT marketplace and an internal area how the ICT infrastructure should be configured and managed [12]. The functional integration dimension covers the strategic integration and the operational integration. In the Luftman's Strategic Alignment Maturity Model (SAMM), the assessment process considers six factors i.e., communication, measurement, governance, partnership, technology scope and skill to assess the maturity of alignment [4]. The Strategic Alignment Model (SAM) is based on building blocks known as strategic fit and functional integration. It represents a distinction between the internal focus and external perspectives of IT. Each of the division subdivides into different alignment perspectives: the former splits into strategy executer and technology transformer, and the latter splits into competitive potential and service level [8]. The BITA models discussed by Mekawy et al. are as follows: Integrated Architecture Framework (IAF), Luftman's Alignment Model (LAM), Reich and Benbasat Model (RBM), Sabherwal and Chan Alignment Model (SCAM), and Hu Huang Alignment Model (HHAM) [8]. Within all the strategic alignment models, the process of alignment is understood as using a certain pattern to bring into unity the relationships between four areas, i.e., strategic execution, technology potential, competitiveness, efficiency and effectiveness of IT services. The other methods are as follows: Scenario-based Architecture Reengineering (SBAR), Tiny Architectural Review Approach (TARA). Scenario-based architectural evaluation is a structural approach to evaluating, how well the architecture meets stakeholder needs, in terms of attributes or qualities.

The capability maturity model provides insight into the stage of development of maturity of an organization for software development. The Architecture Maturity Model (AMM) is based upon capability maturity models as formal ways to gain control over, evaluate and improve architecture processes as well as to assess organization's development competence [11].

The EA evaluation process can be supported by application of software architecture assessment methods. The review of such methods has been done by Ionita et al. [5]. They considered the following methods: Software Architecture Review and Assessment (SARA), Software Architecture Analysis Method (SAAM), Architecture Trade-off Analysis Method (ATAM)[2], Cost Benefit Analysis Method (CBAM), Architecture Level Modifiability Analysis (ALMA), and Family Architecture Analysis Method (FAAM). Beyond that, for software architecture evaluation there are following methods: Architecture Centered Software Project Planning (ACSPP), Architecture Level Prediction of Software Maintenance (ALPSM), Software Architecture Comparison Analysis Method (SACAM).

The EA evaluation for strategic corporate management is supplemented by application of many supplementary methods such as Balanced Scorecard (BSC), Boston Consulting Group (BCG) matrix, the European Foundation for Quality Management (EFQM) model, strengthsweaknesses-opportunities-threats (SWOT) model, market attractiveness of business activity (MABA) model, Michael Porter five forces model, and good practices included in Cobit and Information Technology Infrastructure Library (ITIL). The BSC uses integral performance measurement to track and adjust business strategy. The method enables the integral performance measurement to track and adjust business strategy. 


\section{Project-oriented evaluation approach}

The Table 1 covers characteristics of different composition of projects. The content of the Table 1 is the result of practice work and literature studies $[1,3,7,10]$. In Table 1, the project dimensions including project goals, scope, organization structure, budget, time, resource procurement and accessibility, computer aided project management (CAPM) tools, risk, product and process quality, and contract management are considered. The number of project dimensions can be increased, but at least the characteristics described below ought to be taken into account in the process of evaluation of project composition for enterprise architecture development. Project programme, presented in Table 1, is described as a programme covering different projects as it is in the European Union (UE) funded projects. Roll-out projects are typical for management information systems implementation at commercial organizations. However, it should be noted that for enterprises consisting of a number of fractal organizations, e.g. a franchising network, the roll-out projects approach is also successfully applied.

Table 1. ICTs projects' compositions.

\begin{tabular}{|c|c|c|c|c|c|}
\hline Dimension & Multi-project & $\begin{array}{c}\text { Project } \\
\text { portfolio }\end{array}$ & $\begin{array}{c}\text { Project } \\
\text { Programme }\end{array}$ & $\begin{array}{l}\text { Roll-out } \\
\text { projects }\end{array}$ & Large project \\
\hline Goals & $\begin{array}{l}\text { hierarchy of } \\
\text { projects' goals }\end{array}$ & $\begin{array}{l}\text { competitive } \\
\text { goals, defined } \\
\text { priorities for } \\
\text { particular } \\
\text { projects }\end{array}$ & $\begin{array}{l}\text { goals } \\
\text { defined by } \\
\text { programme } \\
\text { sponsors }\end{array}$ & $\begin{array}{l}\text { project goals } \\
\text { defined } \\
\text { according to } \\
\text { pattern }\end{array}$ & $\begin{array}{l}\text { cohesive } \\
\text { hierarchy of } \\
\text { goals }\end{array}$ \\
\hline $\begin{array}{l}\text { Scope of } \\
\text { projects }\end{array}$ & $\begin{array}{l}\text { mutually } \\
\text { agreed }\end{array}$ & $\begin{array}{l}\text { mutually } \\
\text { disagreed }\end{array}$ & $\begin{array}{l}\text { mutually } \\
\text { consistent }\end{array}$ & $\begin{array}{l}\text { similar to the } \\
\text { pattern }\end{array}$ & $\begin{array}{l}\text { defined for the } \\
\text { whole project }\end{array}$ \\
\hline $\begin{array}{c}\text { Organization } \\
\text { Structure }\end{array}$ & $\begin{array}{l}\text { dispersion or } \\
\text { co-location of } \\
\text { project } \\
\text { members }\end{array}$ & $\begin{array}{l}\text { dispersion or } \\
\text { co-location of } \\
\text { project } \\
\text { members }\end{array}$ & $\begin{array}{l}\text { dispersed or } \\
\text { virtual team }\end{array}$ & $\begin{array}{l}\text { project } \\
\text { members } \\
\text { mobility } \\
\text { according to } \\
\text { requests }\end{array}$ & $\begin{array}{l}\text { dispersion or co- } \\
\text { location of } \\
\text { project members }\end{array}$ \\
\hline Budget & $\begin{array}{l}\text { budget } \\
\text { decision \& } \\
\text { profits } \\
\text { evaluation for } \\
\text { projects }\end{array}$ & $\begin{array}{l}\text { budget } \\
\text { decision \& } \\
\text { profits } \\
\text { evaluation for } \\
\text { portfolio }\end{array}$ & $\begin{array}{l}\text { budget } \\
\text { decision by } \\
\text { sponsors for } \\
\text { all the } \\
\text { projects }\end{array}$ & $\begin{array}{l}\text { each } \\
\text { beneficiary } \\
\text { established } \\
\text { budget } \\
\text { individually }\end{array}$ & $\begin{array}{l}\text { budget decision } \\
\& \text { profits } \\
\text { evaluation for } \\
\text { project }\end{array}$ \\
\hline Time & $\begin{array}{l}\text { sequential or } \\
\text { simultaneous } \\
\text { projects }\end{array}$ & $\begin{array}{l}\text { simultaneous } \\
\text { projects, lack } \\
\text { of task } \\
\text { dependence }\end{array}$ & $\begin{array}{l}\text { schedule } \\
\text { established } \\
\text { by sponsors }\end{array}$ & $\begin{array}{l}\text { sequential or } \\
\text { simultaneous } \\
\text { projects }\end{array}$ & $\begin{array}{l}\text { general schedule } \\
\text { for the project }\end{array}$ \\
\hline $\begin{array}{c}\text { Resource } \\
\text { Procurement } \\
\text { And } \\
\text { Accessibility }\end{array}$ & $\begin{array}{l}\text { central } \\
\text { acquisition \& } \\
\text { division of } \\
\text { resources }\end{array}$ & $\begin{array}{l}\text { project } \\
\text { priorities \& } \\
\text { rivalry for } \\
\text { resources }\end{array}$ & $\begin{array}{l}\text { contest } \\
\text { projects } \\
\text { compete for } \\
\text { resources }\end{array}$ & $\begin{array}{l}\text { possible rivalry } \\
\text { for resources } \\
\text { for } \\
\text { simultaneous } \\
\text { projects }\end{array}$ & $\begin{array}{l}\text { resources } \\
\text { planned for the } \\
\text { whole project }\end{array}$ \\
\hline CAPM & $\begin{array}{l}\text { centralized } \\
\text { database of } \\
\text { projects }\end{array}$ & $\begin{array}{l}\text { autonomous } \\
\text { IT system for } \\
\text { projects }\end{array}$ & $\begin{array}{l}\text { IT support } \\
\text { provided by } \\
\text { sponsors }\end{array}$ & $\begin{array}{l}\text { help desk \& } \\
\text { CRM system } \\
\text { for IT provider }\end{array}$ & $\begin{array}{l}\text { centralized } \\
\text { system for the } \\
\text { project }\end{array}$ \\
\hline Risk & $\begin{array}{l}\text { generally } \\
\text { evaluated \& } \\
\text { reduced } \\
\text { through task } \\
\text { coordination }\end{array}$ & $\begin{array}{l}\text { evaluated on } \\
\text { the particular } \\
\text { projects level }\end{array}$ & $\begin{array}{l}\text { managed on } \\
\text { programme } \\
\text { and projects } \\
\text { level }\end{array}$ & $\begin{array}{l}\text { evaluated } \\
\text { individually for } \\
\text { beneficiaries \& } \\
\text { providers }\end{array}$ & $\begin{array}{l}\text { evaluated for the } \\
\text { whole project \& } \\
\text { tasks }\end{array}$ \\
\hline
\end{tabular}




\begin{tabular}{|c|c|c|c|c|c|}
\hline $\begin{array}{l}\text { Product \& } \\
\text { Process } \\
\text { Quality }\end{array}$ & $\begin{array}{l}\text { centrally } \\
\text { managed \& on } \\
\text { project level }\end{array}$ & $\begin{array}{l}\text { managed on } \\
\text { the project } \\
\text { level }\end{array}$ & $\begin{array}{l}\text { controlled by } \\
\text { sponsors and } \\
\text { project } \\
\text { managers }\end{array}$ & $\begin{array}{l}\text { controlled by } \\
\text { project } \\
\text { performers }\end{array}$ & $\begin{array}{l}\text { controlled for the } \\
\text { whole project }\end{array}$ \\
\hline $\begin{array}{c}\text { Contract } \\
\text { Management }\end{array}$ & $\begin{array}{l}\text { project office } \\
\& \text { managers } \\
\text { are responsible }\end{array}$ & $\begin{array}{l}\text { contracts } \\
\text { agreed on } \\
\text { particular } \\
\text { project level }\end{array}$ & $\begin{array}{l}\text { contracts } \\
\text { signed by } \\
\text { sponsors, } \\
\text { coordinators } \\
\& \text { team } \\
\text { members }\end{array}$ & $\begin{array}{l}\text { contract among } \\
\text { IT providers } \\
\text { and clients }\end{array}$ & $\begin{array}{l}\text { contracts among } \\
\text { project manger } \\
\& \text { IT providers }\end{array}$ \\
\hline
\end{tabular}

Examples of evaluation criteria may include general business criteria, financial criteria, riskrelated criteria, legal regulations compliance criteria, human resources employment criteria, marketing and technical criteria. Evaluation criteria should be based on the enterprise strategies, goals and objectives.

\section{Conclusion}

The project-oriented approach ensures opportunities to include complementary assets and holistically evaluate enterprise architecture. The implementation of a project-oriented approach into the EA development process creates power to increase the EA investment control within a business organization. This may result in increased rigidity and may require the deployment of agile project management methodologies development to ensure organizational flexibility and sustainability. Future research works will focus on applicability of software tools for management and evaluations of the IT projects as well as the systems architecture.

\section{References}

1. A Guide to the Project Management Body of Knowledge (PMBOK Guide). Project Management Institute, Four Campus Boulevard, Newtown Square, Pensylvania (2004)

2. Bass, L., Nord, R., Wood, W., Zubrow, D.: Risk Themes Discovered Through Architecture Evaluations, Technical Report, CMU/SEI-2006-TR-012, ECS-TR-2006-012, Carnegie Mellon, Software Engineering Institute (2006). Accessed at http://www.sei.cmu.edu/library/, May 2013

3. Cohen, I., Mandelbaum, A., Shtub, A.: Multi-project scheduling and control: A processbased comparative study of the critical chain methodology and some alternatives. Project Management Journal, 35, 2 (2004) 39-50

4. Horkoff, J., Yu, E.: Evaluating Goal Achievement in Enterprise Modeling - An Interactive Procedure and Experiences. In: Persson, A., Stirna, J.(eds.): The Practice of Enterprise Modeling. Springer, Laxenburg (2009) 145-160

5. Ionita, M.T., Hammer, D.K., Obbink, H.: Scenario Based Software Architecture Evaluation Methods; an Overview (2002). Accessed at http://ebookbrowse.com/scenario-based-swa-evaluation-met.retrieved, May 2012

6. ISO/IEC/IEEE 42010 International Standard. Systems and software engineering Architecture description. ISO, Geneva (2011) 
7. Kendall, G.I., Rollins, S.C.: Advanced Project Portfolio Management and the PMO: Multiplying ROI at Warp Speed. J.Ross Publishing, Boca Raton (2003)

8. Mekawy, M.E., Rusu, L., Ahmed, N.: Business and IT Alignment: An Evaluation of Strategic Alignment Models. In: Lytras, M.D., Ordonez de Pablos, P., Damiani, E., Avison, D., Naeve, A., Horner, D.G (eds.): Best Practices for the Knowledge Society, Knowledge, Learning, Development and Technology for All. Springer Berlin (2009) 447-455

9. Minoli, D.: Enterprise Architecture A to Z, Frameworks, Business Process Modeling, SOA, and Infrastructure Technology. CRC Press, London (2008)

10. Slovjak M.: SAP Rollout Project (2002). Accessed at http://www.open.hr/hiz/hrusko/RolloutPresCASE3.pdf , May 2012

11. Van Den Berg, M., Van Steenbergen, M.: Building an Enterprise Architecture Practice, Tools, Tips, Best Practices, Ready-to-Use Insights. Springer, Sogeti (2006)

12. Van Grembergen, W.: Strategies for Information Technology Governance. Information Science Reference, IGP, Hershey, PA (2004) 